\title{
The Relationship of Indonesian Language Learning with the Environment
}

\author{
Sekar Arum/19016123
}

sekararummaret@gmail.com

The use of language cannot be separated when socializing with the surrounding environment. Likewise in learning Indonesian, the environment is very influential in the student learning process. The relationship between the environment and learning Indonesian is very close and complementary to each other. According to Dardjowidjojo (in Ramadhan et al, 2019) children will naturally recognize language as a way of communicating with those around them. The first language known and subsequently mastered by a child is called the mother tongue (native language). Furthermore, Yogatama (in Ramadhan et al, 2019) said that the acquisition of the first language is closely related to the social development of children and the formation of social identity. Learning the first language is one of the overall developments of children as members of a society.

Ramadhan et al (2019) said that from an early age, babies have interacted in their social environment. A mother often provides opportunities for babies to participate in social communication, so that's when the baby first gets to know socialization that this world is a place where people share feelings. Through the first language (B1), a child learns to be a member of society. B1 becomes one of the means to express feelings, desires, and opinions, in the forms of language that are considered to exist. Children also learn that there are forms that cannot be accepted by members of the community, children should not always express their feelings openly. The acquisition of the first language or mother tongue of children around the world is the same. The similarity of the acquisition process is not only caused by the similarities of the biological and neurological elements of language, but also by the aspect of Arifuddin's language mentality (in Ramadhan et al, 2019).

According to Sukma (2020) low levels of knowledge and understanding of information in Indonesia are often associated with low levels of public literacy. In this sense, literacy can be interpreted as insight and individual ability to process information and knowledge for life skills. Ramadhan et al (2019) stated that in Indonesia, in line with the curriculum changes in 2013, the government launched the School Literacy Movement (GLS) program to improve student literacy. The movement is not only intended for students, but is aimed at society in general. Apart from this, the teacher is a very decisive component in the implementation of a strategy in making the learning process effective. The success of implementing a learning strategy depends on the expertise of the teacher in using the teaching methods, techniques and tactics Radesi (in Ramadhan et al, 2018). However, students' writing learning outcomes are still low. This is because when learning to write takes place the teacher still uses teaching materials that are less attractive, the learning process is still teacher-centred so that students cannot learn independently, even though the abilities, speed, and understanding of students are different and the teacher is still concerned with the results rather than the results process (Ramadhan et al, 2015). 
Ramadhan et al (2013) said that in an effort to determine the level of the role of attitudes and learning motivation on learning outcomes, especially in Indonesian language lessons, it is necessary to observe and analyze these attitudes and learning motivations. Knowing students' attitudes and learning motivation helps teachers or schools in formulating various strategies that should be planned in developing teaching and learning activities, especially in Indonesian language lessons. The above can be overcome by developing individuals who are aware and responsible for the environment needed to deal with these problems so that the environment and quality of life are sustainable for the better. This can be realized through education, more specifically environmental education (Ramadhan et al, 2019).

Environmental education is a collective effort that is consciously organized to teach or attract human attention about how the natural environment functions and how these humans can manage and protect it. As stated by Ode (in Ramadhan et al, 2019) explaining "politeness as behavior that is expressed in a good or ethical way and is a cultural phenomenon, so what is considered polite by one culture may not be the case with other cultures." This means that politeness is a very important aspect of language because it can facilitate interaction between individuals. This education takes place in the practice of seeking creativity and discovery, and the exploration of reality without realizing it. Developing knowledge about the social and scientific importance of the environment is the first step in establishing a community-friendly environment.

According to Sukma (2020) one solution that can be done to overcome environmental problems is with the correct knowledge of all environmental factors to protect the environment. The most effective effort to achieve this goal is an adequate environmental education system, mapped out and aimed at providing awareness, conscience and information on environmental issues to students of all levels. Increased awareness about the environment can be obtained through the educational process. Education is a key element in the prevention and resolution of environmental problems. Likewise, language learning itself is the foundation on which other academic skills are built (Sukma et al, 2020). Language is used in various fields such as economics, law, politics, and education. In education, especially language education, the use of language is packaged in four language skills, namely listening, speaking, reading, and writing. Furthermore, reading is a basic language skill needed for academic and social life. (Sukma et al, 2020).

Based on the questionnaire that the author distributed on "The Relationship of Indonesian Language Learning with the Environment" to a number of respondents with a total of 36 respondents with the percentage of male respondents being $5.6 \%$ and female respondents being $94.4 \%$. The results of the data from the percentage of questionnaires that have been carried out through the google form can be seen as follows. The first statement, "Introduction to the environment is very influential on learning Indonesian language" 69.4\% stated Strongly Agree, 30.6\% stated agree, 0\% stated disagreed, and $0 \%$ disagreed. The second statement, "The application of the Indonesian language can be taught from an early age from the environment, both formal and informal environments" 88.9\% stated Strongly Agree, 11.1\% stated agreed, $0 \%$ stated disagreed, and $0 \%$ stated disagreed. The third statement, "The introduction of environmental education is important to be included in learning in order to raise awareness of students in protecting the surrounding environment" $72.2 \%$ stated Strongly Agree, $27.8 \%$ agreed, $0 \%$ disagreed, and $0 \%$ disagreed. The fourth statement, 
"The environment has a great influence on children's language development" $80.6 \%$ stated Strongly Agree, 19.4\% agreed, 0\% disagreed, and 0\% disagreed. The fifth statement, "Integrating environmental education in the Indonesian language learning process is one way to realize and develop students' abilities, so that students can innovate and collaborate with the environment around them" $61.1 \%$ strongly agree, $38.9 \%$ agree , $0 \%$ disagreed, and $0 \%$ disagreed. The sixth statement, "The quality of Indonesian language learning in the school environment, is influenced by the learning methods applied by the teacher, and students' interest in learning" 58.3\% stated Strongly Agree, $33.3 \%$ agreed, $8.3 \%$ disagreed, and $0 \%$ disagree. The seventh statement, "Through the environment, students are able to develop ecological abilities, think creatively, be innovative, and are able to increase students' awareness of the importance of protecting the environment" 63.9\% stated Strongly Agree, 36.1\% agreed, $0 \%$ disagreed, and $0 \%$ disagree. The eighth statement, "In learning Indonesian in schools, teachers must give importance to environmental materials in learning Indonesian in schools to maintain environmental sustainability" $69.4 \%$ strongly agree, $30.6 \%$ agree, $0 \%$ disagree, and $0 \%$ disagree. The ninth statement, "There is still a lack of awareness of the importance of the environment in learning Indonesian" 36.1\% stated Strongly Agree, 50\% agreed, 8.3\% disagreed, and 5.6\% disagreed. And the tenth statement, "Returning to nature is the right reference to make the environment (nature) a source of inspiration to build linguistic intelligence" $41.7 \%$ strongly agree, $44.4 \%$ agree, $11.1 \%$ disagree, and $2.8 \%$ disagreed.

From the results of the questionnaires that have been distributed, the authors can conclude that the environment has a very close and important relationship in learning Indonesian. It is evident when the respondents consider that the relationship between learning Indonesian and the environment is an important thing. The community, especially among students and students, realizes and understands the close relationship between the environment in learning Indonesian. According to the author, public awareness of environmental links in Indonesian language learning can be categorized as good. The application of environmental links with Indonesian language learning can make it easier for teachers and students to teach and understand Indonesian language material that is motivating, creative, fun, and useful. 


\section{REFERENCES}

Gani, E., Noibe Halawa, and Syahrul R. (2019). Indonesian Language Politeness in Prohibiting and Criticizing the Seven Ethnicities. Journal of Language, Literature, and Its Teaching, XV(2), 195-205.

Ramadhan, S., Elfia Sukma, and Vivi Indriyani. (2019). Environmental Education and Disaster Mitigation Through Language Learning. IOP Conference Series: Earth and Environmental Science, 314, p. 1-9.

Ramadhan, S., Indah Permatasari Suardi, and Yasnur Asri. (2019). First Language Acquisition in Early Childhood. Journal of Obsession: Journal of Early Childhood Education, 3(1), 265 - 273.

Ramadhan, S., Mina Syanti Lubis, and Novia Juita. (2015). Development of Indonesian Language Learning Modules Assisted by Mind Maps in Writing Materials for Class Xi Senior High School Students. Journal of Language, Literature and Learning, 2(1), 17-28.

Ramadhan, S., M. Zaim, Atmazaki, and Vivi Indriyani. (2019). Literacy, Reading and Language Curriculum Innovation. Scientific Journal of Language, Literature, and Its Teaching, 5(1), 108-118.

Ramadhan, S., Yuliana Sari, and Yulianti Rasyid. (2018). The Relationship Between Reading Comprehension Skills and Writing Text Skills on Observation Results of Class X Smk Negeri 3 Padang Students. Journal of Indonesian Language and Literature Education, 7(3), 446-453.

Sukma E. et. al. (2020). Compentency of Elementary School Teacher In Written Language Learning. 2300712.

Sukma E., Syahrul Ramadhan, and Vivi Indriyani. (2020). Design of Learning Modules Writing Narrative Text Based on Project Based Learning (PjBL) by Using Mobile Devices. Journal of Physics: Conf, Series 1471, 1-9.

Sukma, E., Syahrul R, dan Vivi Indriyani. (2020). Integration of Environmental Education in Elementary Schools. Journal of Physics: Conf. Series 1481, 1-6.

Sukma E. et. al. (2019). Models of Literacy Media in Improving Reading Skill of Early Grade Students. Primary Teacher Education Program. 11-12.

Zulhafizh, Atmazaki, and Syahrul Ramadhan. (2013). Contribution of Students' Attitudes and Learning Motivation to Indonesian Language Learning Outcomes. Journal of Language, Literature and Learning, Volume 1, Number 2, Pages 13-28. 